\title{
PELATIHAN PERAWATAN DAN PERBAIKAN RANGKA KENDARAAN BERMOTOR UNTUK MENINGKATKAN PEMAHAMAN DAN KUALITAS PELAYANAN BENGKEL WARGA DESA SRIKAMULYAN
}

\author{
Murtalim \\ Teknik Mesin, Fakultas Teknik Dan Ilmu Komputer, Universitas Buana Perjuangan Karawang \\ Jalan Ronggo Waluyo Sirnabaya, Puseurjaya, Kec. Telukjambe Timur, Kabupaten Karawang, Jawa \\ Barat 41361 \\ E-mail: murtalim@ubpkarawang.ac.id.
}

\begin{abstract}
ABSTRAK
Desa Srikamulyan terletak di Kecamatan Tirtajaya, Kabupaten Karawang, Propinsi Jawa Barat dengan jumlah penduduk 7.381 orang yang terdiri dari 3.742 laki-laki dan 3.639 perempuan. Di desa Srikamulyan saat ini terdapat 6 usaha bengkel motor, Namun belum banyak warga yang mengetahui bagaimana kualitas pelayanan yang baik pada bidang usaha tersebut. Oleh karena itu melalui pengabdian masyarakat prodi teknik mesin Universitas Buana Perjuangan Karawang dengan tema pelatihan ini diharapkan warga desa mengetahui dan meningkatkan kualitas pelayanan yang baik kepada pelanggannya di bidang usaha bengkel sepeda motor. Pelatihan ini terdiri dari dua sesi yaitu sesi teori dan dilanjutkan sesi praktek teknik perawatan motor. Pada sesi teori dan praktikum ini disampaikan untuk mempertahankan performa kendaraan, maka kendaraan harus dirawat secara berkala. Pelatihan ini berjalan dengan lancar, pada sesi teori diselenggarakan di aula desa Srikamulyan sedangkan sesi praktek diselenggarakan di halaman kantor desa Srikamulyan. Pada sesi praktek sepeda motor yang digunakan adalah Honda Beat dan Honda supra $x 125$.
\end{abstract}

Kata kunci : desa Srikamulyan, pengabdian kepada masyarakat, perawatan sepeda motor, bagian rangka kendaraan.

\begin{abstract}
Srikamulyan Village is located in the Tirtajaya District, Karawang Regency, West Java Province with a population of 7,381 people consisting of 3,742 men and 3,639 women. In Srikamulyan village, there are currently 6 motorcycle repair shops. However, not many residents know how good the quality of service is in this business sector. Therefore, through the community service of the mechanical engineering study program, University of Buana Perjuangan, Karawang with the theme of this training, it is hoped that the villagers will know and improve the quality of good service to customers in the motorcycle repair business sector. This training consists of two sessions, namely a theory session and followed by a practical session on motor maintenance techniques. In this theory and practicum session, it was conveyed that to maintain vehicle performance, the vehicle must be regularly maintained. This training went well, the theory session was held in the village hall of Srikamulyan while the practical session was held in the courtyard of the village office of Srikamulyan. In the practical session, the motorbikes used were Honda Beat and Honda Supra x 125
\end{abstract}

Keywords: srikamulyan village, community service, motorcycle maintenance, vehicle frame parts. 


\section{PENDAHULUAN}

Desa Srikamulyan adalah satu desa yang terletak di Kecamatan Tirtajaya, Kabupaten Karawang, Propinsi Jawa Barat(Badan Pusat Statistik Kabupaten Karawang, 2019). Secara geografis teletak di garis pantai utara yang berdekatan dengan laut jawa dengan tinggi wilayah hanya 5 meter diatas pemukaan laut, dengan jarak tempuh 7,1 km ke ibukota Kecamatan dan 42,4 km ke ibukota Kabupaten.

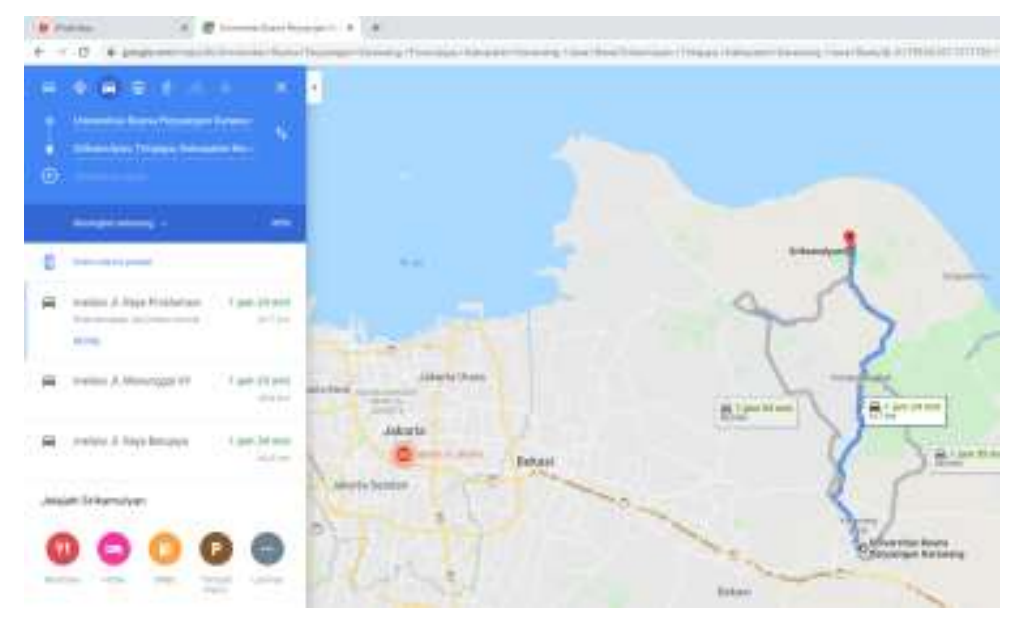

Gambar 1. Lokasi desa Srikamulyan di dalam peta

Luas Desa Srikamulyan adalah $7,6 \mathrm{~km}^{2}$ atau sekitar $8,08 \%$ dari total wilayah Kecamatan Tirtajaya, memiliki 4 dusun (Kedungasem, Jati Tengah, Ciwaru I dan Cirawu II), 4 Rukun Warga (RW) dan 8 Rukun Tetangga (RT) dengan jumlah Rumah Tangga 2.644 KK, dan jumlah penduduk 7.381 orang, terdiri dari 3.742 laki-laki dan 3.639 perempuan. Secara geografis batas wilayah Desa Srikamulyan adalah sebagai berikut:

- Sebelah Utara

- Sebelah Selatan

- Sebelah Barat

- Sebelah Timur
: Desa Sedari

: Desa Kedung jeruk

: Desa Tambak sumur

: Desa Kuta makmur 


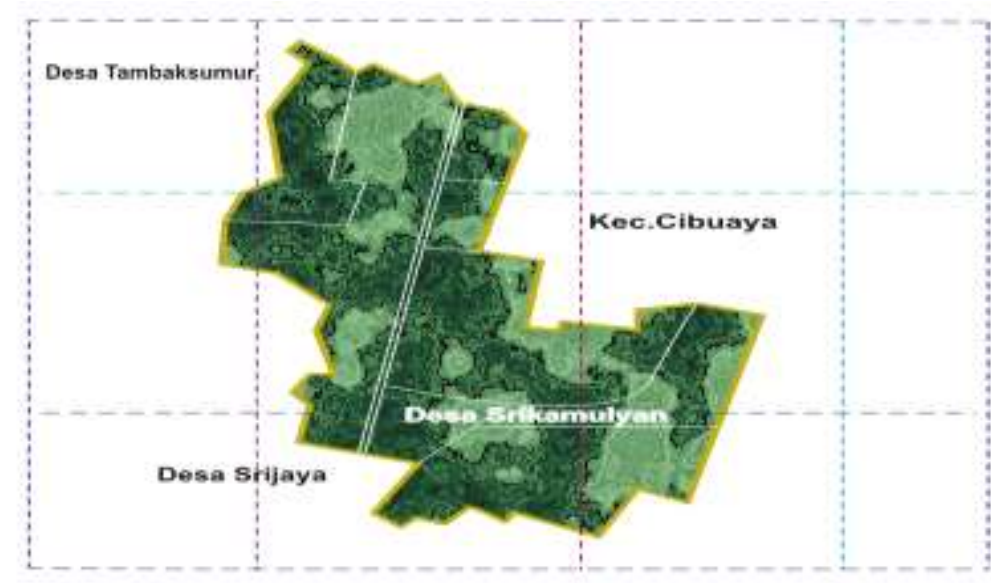

Gambar 2. Peta Desa Srikamulyan, Kecamatan Tirtajaya, Kabupaten Karawang

Desa Srikamulyan dipimpin oleh seorang Kepala Desa. Aparatur desa Srikamulyan memiliki latar belakang pendidikan SD/sederajat berjumlah 17 orang, SLTP/sederajat berjumlah 7 orang dan SMU/sederajat berjumlah 5 orang. Kondisi mata pencaharian masyarakat Desa Srikamulyan sebagian besar bekerja sebagai nelayan, buruh tani (sebagian besar), pedagang, dan karyawan swasta.

Karang Taruna merupakan organisasi yang dibentuk oleh masyarakat sebagai potensi dan sumber kesejahteraan social. Karang Taruna berkedudukan di Desa atau Kelurahan di dalam wilayah hukum Negara Kesatuan Republik Indonesia (Peraturan Menteri Sosial Republik Indonesia Nomor 25 Tahun 2019 Tentang Karang Taruna, 2019). Keberadaan karang taruna yang mayoritas berisi generasi muda yang produktif sangat diperlukan di tengah-tengah masyarakat sebagai penggerak dan agen perubahan dalam rangka pencapaian tujuan bersama yaitu kesejahteraan masyarakat. Salah satu upaya pencapaian kesejahteraan adalah dengan memperbaiki tingkat perekonomian masyarakat setempat. Oleh karena itu, dibutuhkan pembekalan dan pelatihan yang mendukung upaya tersebut seperti pelatihan motivasi berwirausaha, kewirausahaan, manajemen bisnis, koperasi, dan lain-lain.

Kegiatan pengabdian yang dikemas dalam bentuk pelatihan yang mengkombinasikan teori dan praktik dinilai sangat efektif, karena peserta dapat secara langsung mempraktikannya keterampilannya tanpa rasa ketakutan gagal atau rusak, karena kegiatan praktik dalam bimbingan tim pelaksana (Rahdiana, 2019). Dengan pelatihan-pelatihan semacam itu diharapkan semangat dan motivasi anggota karang taruna dapat terpacu sehingga akan muncul unit-unit bisnis/usaha yang baru dan dapat memberdayakan masyarakat setempat yang pada akhirnya akan meningkatkan tingkat perekonomian masyarakat. Disisi lain, lembaga Pendidikan Tinggi atau Universitas harus selalu menjunjung tinggi dan melaksanakan Tri Dharma Perguruan Tinggi yang salah satunya adalah kegiatan Pengabdian Kepada Masyarakat. Oleh karena itu, dalam rangka kegiatan Pengabdian Kepada Masyarakat dan 
mempertimbangkan pentingnya pembekalan dan pelatihan mengenai kewirausahaan kepada karang taruna sebagai penggerak masyarakat.

Program Studi Teknik Mesin, Fakultas Teknik dan Ilmu Komputer, Universitas Buana Perjuangan Karawang mengadakan kegiatan Pelatihan Teknik Mesin Otomotif Tahun 2019 kepada anggota karang taruna Desa Srikamulyan, Kecamatan Tirtajaya, Kabupaten Karawang. Unit usaha yang dijadikan model adalah usaha jasa perawatan sepeda motor. Sepeda motor adalah kendaraan beroda dua yang digerakkan oleh sebuah mesin (Pemeliharaan Mesin Sepeda Motor 2, 2016).

Tujuan kegiatan pengabdian kepada masyarakat ini adalah sebagai berikut:

1. Memberikan pelatihan keterampilan tentang perawatan/servis kendaraan roda dua kepada anggota Karang Taruna desa Srikamulyan.

2. Untuk mengurangi tingkat pengangguran usia produktif yang tidak memiliki keterampilan di desa Srikamulyan.

3. Untuk mendukung program pemerintah daerah mewujudkan desa Srikamulyan yang maju, makmur dan mandiri.

Manfaat kegiatan pengabdian kepada masyarakat yang dikemas dalam bentuk pelatihan perawatan kendaraan bermotor roda dua, ini adalah sebagai berikut:

1. Bagi karang taruna dan masyarakat desa Srikamulyan

a. Meningkatkan pengetahuan dan keterampilan masyarakat khususnya anggota karang taruna desa Srikamulyan tentang perawatan/ servis kendaraan roda dua yang diharapkan menjadi modal awal untuk membuka unit bisnis/ usaha yang baru.

b. Diharapkan mampu mengurangi tingkat pengangguran usia produktif yang tidak memiliki keahlian di desa Srikamulyan.

c. Diharapkan mampu mendorong terwujudnya desa Srikamulyan yang maju, makmur dan mandiri.

2. Bagi civitas Program Studi Teknik Mesin, Fakultas Teknik dan Ilmu Komputer, Universitas Buana Perjuangan Karawang.

a. Dapat melaksanakan kegiatan pengabdian kepada masyarakat sebagai bentuk perwujudan Tri Dharma Perguruan Tinggi.

b. Sebagai bentuk sosialisasi dan kedekatan insan akademik ditengah-tengah masyarakat untuk mendorong program-program pemerintah dalam upaya pembangunan dan peningkatan kesejahteraan masyarakat desa.

\section{METODE}

Metode kegiatan yang dilakukan adalah pelatihan perawatan kendaraan bermotor roda dua kepada Karang Taruna Desa Srikamulyan, Kecamatan Tirtajaya, Kabupaten Karawang 
yang terdiri dari dua sesi yaitu sesi teori dan praktek.

Langkah-langkah yang dilakukan untuk penyelenggaraan kegiatan Pengabdian Kepada Masyarakat ini adalah sebagai berikut:

1. Tahap Pelaksanaan

Tahap pelaksanaan pelatihan dibagi dalam 2 (dua) sesi, yaitu:

a. Sesi teori

Pada sesi ini akan diberikan penjelasan secara teoritis tentang sistem perawatan kendaraan bermotor roda dua, yang terdiri dari: jenis-jenis servis, peralatan servis, fungsi bagian-bagian dari kendaraan bermotor, cara perawatan kendaraan bermotor, dan teknik perbaikan sepeda motor.

b. Sesi praktek

Pada sesi kedua ini peserta pelatihan akan diajak secara langsung untuk melakukan praktek servis atau perbaikan sepeda motor secara berkelompok.

2. Tahap Evaluasi

Evaluasi kegiatan dilakukan terhadap aspek pencapaian tujuan Pengabdian Kepada Masyarakat secara keseluruhan, tujuan pelatihan, dan juga penyelenggaraan pelatihan itu sendiri.

\section{HASIL DAN PEMBAHASAN}

Kegiatan pengabdian kepada masyarakat yang dilaksanakan pada tanggal 30 November 2019 di aula desa Srikamulyan dihadiri oleh lima belas orang warga masyarakat (Perangkat Desa dan Karang Taruna Desa Srikamulyan), delapan belas orang dosen Universitas Buana Perjuangan Karawang yang terdiri dari dua belas orang dosen Teknik Industri dan enam orang dosen Teknik Mesin, sebelas orang mahasiswa dari Himpunan Mahasiswa Teknik Industri (HMTI), lima belas orang mahasiswa dari Himpunan Mahasiswa Teknik Mesin (HMTM).

Tabel 1. Peserta Pelatihan Kegiatan Pengabdian Kepada Masyarakat

\begin{tabular}{|c|c|c|c|}
\hline No & Nomor KTP & $\begin{array}{c}\text { Nama } \\
\text { Peserta }\end{array}$ & Keterangan \\
\hline 1 & 3215091502810004 & Ade Saron & Karang Taruna Ds. Srikamulyan \\
\hline 2 & 3215090510880008 & Samsudin & Karang Taruna Ds. Srikamulyan \\
\hline 3 & 3215090504800006 & Nurjamil & Karang Taruna Ds. Srikamulyan \\
\hline 4 & 3215092912930002 & Abdurohman & Karang Taruna Ds. Srikamulyan \\
\hline
\end{tabular}




\begin{tabular}{|c|c|c|c|}
\hline 5 & 3215091507930004 & Suheri & Karang Taruna Ds. Srikamulyan \\
\hline 6 & 3215091511930006 & Mustika & Karang Taruna Ds. Srikamulyan \\
\hline 7 & 3215091405950005 & Dede Hidayat & Karang Taruna Ds. Srikamulyan \\
\hline 8 & 3215090107940112 & Asep & Karang Taruna Ds. Srikamulyan \\
\hline 9 & 3215092102960002 & Badru Jamal & Karang Taruna Ds. Srikamulyan \\
\hline 10 & 3215091204880009 & Rohman & Karang Taruna Ds. Srikamulyan \\
\hline 11 & 3215090107940112 & Samsul Hadi & Karang Taruna Ds. Srikamulyan \\
\hline 12 & 3215112203910003 & Riswanto & Karang Taruna Ds. Srikamulyan \\
\hline 13 & 3215090903910007 & Andriansyah & Karang Taruna Ds. Srikamulyan \\
\hline 15 & 3215092809000003 & Yudi & Karang Taruna Ds. Srikamulyan \\
\hline & & Hidayat & Karang Taruna Ds. Srikamulyan \\
\hline
\end{tabular}

Pelatihan ini berjalan dengan lancar, pada sesi teori diselenggarakan di aula desa Srikamulyan sedangkan sesi praktek diselenggarakan di halaman kantor desa Srikamulyan. Pada sesi praktek sepeda motor yang digunakan adalah Honda Beat, Honda Revo, Honda Supra, Yamaha MX, Yamaha $\mathrm{X}$ Ride. Seksi praktek ini dilakukan untuk mempersiapkan mekanik yang terampil dalam melakukan perawatan sepeda motor sehingga bisa memberikan kualitas pelayanan yang handal. Pada sesi praktek dibagi menjadi 5 (lima) tim yang masing masing tim menggunakan satu unit sepeda motor. Pembagian tim bisa dilihat pada tabel 2 dibawah ini :

Tabel 2. List Peserta Pelatihan dalam Bentuk Tim

\begin{tabular}{|c|c|c|c|c|}
\hline Tim & $\begin{array}{c}\text { Peserta } \\
\text { Pelatihan }\end{array}$ & $\begin{array}{c}\text { Dosen } \\
\text { Pendamping }\end{array}$ & $\begin{array}{l}\text { Mahasiswa } \\
\text { Pendamping }\end{array}$ & Jenis Motor \\
\hline \multirow{3}{*}{$\begin{array}{c}\text { Tim } \\
\text { A }\end{array}$} & Ade Saron & \multirow{3}{*}{$\begin{array}{l}\text { Nana } \\
\text { Rahdiana }\end{array}$} & Falahal Majid & \multirow{3}{*}{ Jupiter MX } \\
\hline & Samsudin & & Gusti Pratama & \\
\hline & Nurjamil & & Roy Purba & \\
\hline \multirow{3}{*}{$\begin{array}{c}\text { Tim } \\
\text { B }\end{array}$} & Abdulrohman & \multirow{3}{*}{ Sunandar } & Fajar A Fauzi & \multirow{3}{*}{ Honda Beat } \\
\hline & Suheri & & Rangga Permana & \\
\hline & Mustika & & Dimas Rizqie & \\
\hline \multirow{3}{*}{$\begin{array}{c}\text { Tim } \\
\mathrm{C}\end{array}$} & Dede Hidayat & \multirow{3}{*}{ Afif Hakim } & Eko Afriyansyah & \multirow{3}{*}{ Honda Revo } \\
\hline & Asep & & Diki Herdiansyah & \\
\hline & Badru Jamal & & Tito C. Pratama & \\
\hline Tim & Rohman & Sumanto & Iqbal Maulana & Yamaha X- \\
\hline
\end{tabular}




\begin{tabular}{|c|l|l|l|l|}
\hline \multirow{2}{*}{ D } & Samsul Hadi & & Deri & Ride \\
\cline { 2 - 2 } & Riswanto & & Muhamad Ichwan & \\
\hline \multirow{2}{*}{ Tim } & Andriansyah & & Ridho & \multirow{2}{*}{ Honda Supra X } \\
E & W. Hidayat & Murtalim & Riyan Ardianto & 125 \\
\cline { 4 - 5 } & Yudi & & Ragil & \\
\hline
\end{tabular}

Beberapa dokumentasi dalam bentuk foto saat acara pelatihan perawatan kendaraan bermotor roda dua dapat dilihat pada beberapa gambar dibawah ini :

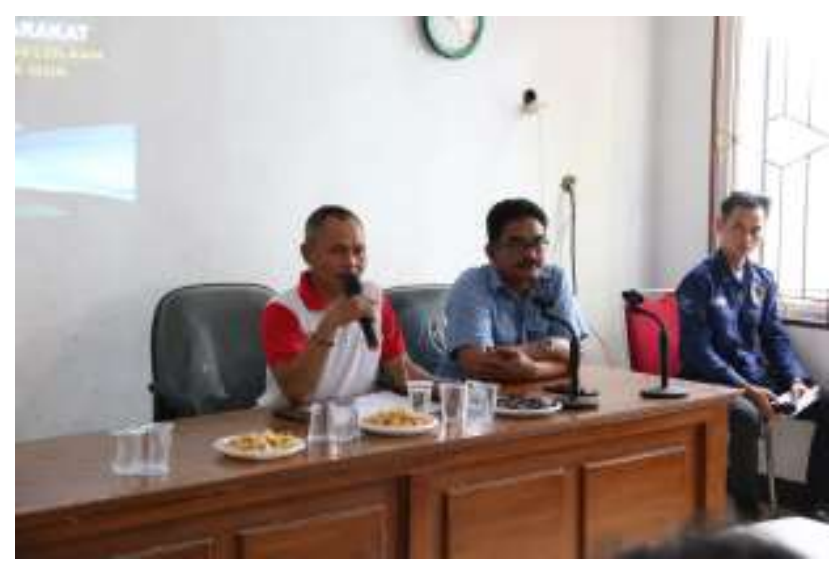

Gambar 3. Pembukaan Pelatihan oleh Kepala Desa Srikamulyan

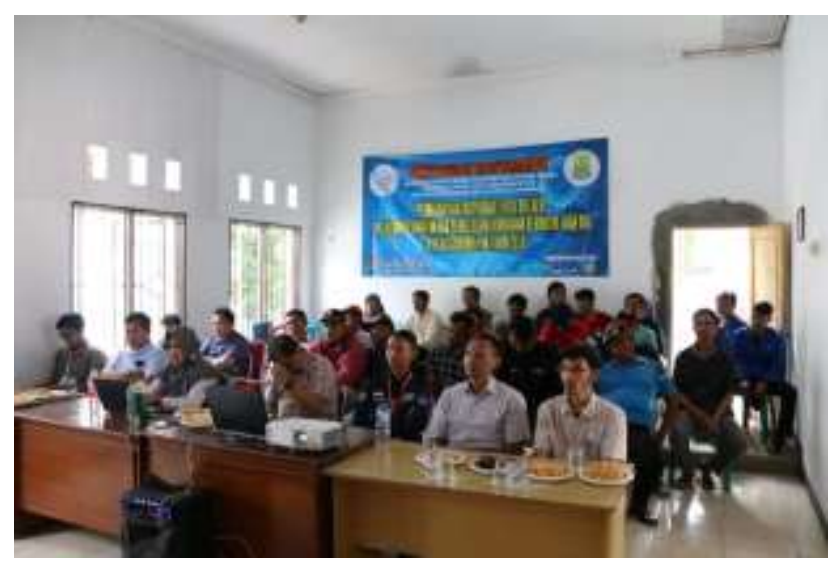

Gambar 4. Sesi Teori di Aula Desa Srikamulyan 


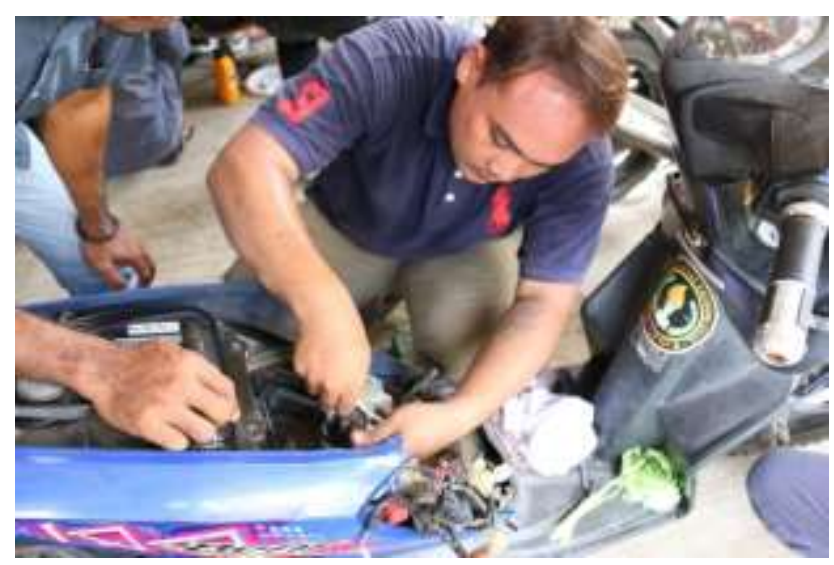

Gambar 5. Sesi Praktek di Halama Kantor Desa Srikamulyan

Pengabdian kepada masyarakat ini merupakan kegiatan yang dilakukan kedua kalinya di desa Srikamulyan, setelah kegiatan pertama pada awal tahun 2019. Namun kegiatan pengabdian kepada masyarakat ini mengusung tema yang berbeda yaitu 'Pemberdayaan Masyarakat Desa Melalui Pelatihan Perawatan dan Pengelolaan Kendaraan Bermotor Roda Dua di Desa Srikamulyan'. Adapun Judul yang disampaikan pada pelatihan ini adalah "Perawatan dan perbaikan bagian rangka sepeda motor supra X 125 di Karang Taruna Desa SrikaMulyan Kecamatan Tirtajaya Kabupataen Karawang”.

Pelatihan ini terdiri dari dua sesi yaitu sesi teori dan dilanjutkan sesi praktek teknik perawatan sepeda motor. Pengabdian kepada masyarakat yang dikemas dalam bentuk pelatihan ini terselenggara berkat kerjasama antara Program Studi Teknik Industri dan Teknik Mesin Universitas Buana Perjuangan Karawang, dengan Pemerintah Desa dan Karang Taruna Desa Srikamulyan. Foto-foto kegiatan ditampilkan pada Lampiran.

Pada sesi teori dan praktikum ini disampaikan bahwa untuk dapat kendaraan yang handal dan mempertahankan feforrme kendaraan maka perlunya kendaraan itu diservis atau di perbiki maka perlu di lakukan perawatan berkala atau servis..

Pelatihan ini berjalan dengan lancar, pada sesi teori diselenggarakan di aula desa Srikamulyan sedangkan sesi praktek diselenggarakan di halaman kantor desa Srikamulyan. Pada sesi praktek digunakan lima kendaraan yaitu Honda Beat B 6531, Yamaha MX B T 4101 F, Yamaha X Ride T 5744 NF, Honda Supra X 125 B 6104 KWJ dan Honda Revo T 5836 F. Seksi praktek ini dilakukan untuk mempersiapkan mekanik yang terampil dalam melakukan perawatan sepeda motor sehingga bisa memberikan kualitas pelayanan yang handal. 
Tabel 3. Item Check Perawatan bagian kerangka Sepeda Motor

\begin{tabular}{|l|l|l|l|l|l|}
\hline \multirow{2}{*}{ No } & \multirow{2}{*}{ Item } & \multicolumn{2}{|c|}{ Kondisi } & \multirow{2}{*}{ Ket. } \\
\cline { 2 - 4 } & & Bagus & $\begin{array}{c}\text { Layak } \\
\text { Pakai }\end{array}$ & Ganti & \\
\hline 1 & Periksa kondisi dan keausan rem & & & & \\
\hline 2 & Penyetelan jarak main bebas untuk rem & & & & \\
\hline 3 & Pemeriksaan minyak rem & & & \\
\hline 4 & Lakukan penyetelan pada stang stir & & & \\
\hline 5 & Pastikan fork depan tidak oblak & & & \\
\hline 6 & Periksa bearing roda dan kelainan suara & & & & \\
\hline 7 & Periksa kekendoran mur \& baut & & & \\
\hline 8 & Periksa jarak main bebas roda dengan & & & \\
\hline 9 & swing arm pivot & & & \\
\hline 10 & Periksa kelonggaran jari-jari & & & \\
\hline 11 & Pemeriksaan Keolengan Roda & & & \\
\hline 12 & Periksa tekanan angin & & & \\
\hline 13 & Pemeriksaan keauasan ban & & & \\
\hline 14 & Ukuran ban yang di anjurkan untuk roda & & & & \\
\hline 15 & Pemeriksaan stang kemudi & & & \\
\hline 16 & Pemeriksaan keausan gird & & & \\
\hline 17 & Pelumasan dan pembersihan rantai & & & \\
\hline 18 & Pemeriksaan sprocket dari keausan dan & & & \\
\hline 19 & Petak & & & \\
\hline 20 & Periksa Pemasangan "Chain Clip" pada & & & \\
\hline
\end{tabular}

Catatan: Berikan tanda $\sqrt{ }$ pada kolom kondisi sesuuai hasil pengecekan

\section{KESIMPULAN DAN SARAN}

A. Kesimpulan

Pengabdian kepada masyarakat ini mampu memberikan pengetahuan kepada sebagian masyarakat Desa Srikamulyan sehingga mereka mengetahui kualitas pelayanan 
yang baik pada usaha bengkel sepeda motor. Dengan demikian diharapkan mereka dapat menerapkan pengetahuan dan keterampilan yang telah diperolehnya.

\section{B. Saran}

Masyarakat disarankan untuk selalu memperhatikan kualitas pelayanan usaha bengkel sepeda motor yang telah atau akan ditearpkan, sehingga pelanggan dapat loyal pada usahanya dan bahkan bertambah banyak.

Para pengusaha perbengkelan sepeda motor diharapkan juga untuk memberikan pelatihan kursus lanjutan standar perbaikan dan perawatan sepeda motor agar kemampuan para operator bengkel dapat lebih meningkat dan memberikan kepuasan terhadap pelanggannya, dan pada akhirnya akan lebih meningkatkan penghasilan bagi para operator dan juga pengusahanya.

\section{DAFTAR PUSTAKA}

Badan Pusat Statistik Kabupaten Karawang. (2019). Kecamatan Tirtajaya Dalam Angka. Badan Pusat Statistik Kabupaten Karawang. https://karawangkab.bps.go.id/publication/2019/09/26/64550f5b09971e90f9b61838/kecamatantirtajaya-dalam-angka-2019

Pemeliharaan Mesin Sepeda Motor 2. (2016). Kementrian Pendidikan dan Kebudayaan Republik Indonesia.

Peraturan Menteri Sosial Republik Indonesia Nomor 25 Tahun 2019 Tentang karang Taruna. (2019). Kementrian Sosial Republik Indonesia. https://jdih.kemsos.go.id/pencarian/www/storage/document/PERMENSOS NOMOR 25 TAHUN 2019.pdf

Rahdiana, N. (2019). Pelatihan Mesin Otomotif Bagi Masyarakat Desa. Jurnal Buana Pengabdian, 1(2), 9-19. https://doi.org/https://doi.org/10.36805/jurnalbuanapengabdian.v1i2.1068 